\title{
Summer and Winter Defoliation Impacts on Mixed-Grass Rangeland
}

\author{
Alexander J. Smart, ${ }^{1}$ Roger N. Gates, ${ }^{2}$ Patricia S. Johnson, ${ }^{2}$ and Rebecca Schafer ${ }^{3}$ \\ Authors are ${ }^{1}$ Professor, Department of Natural Resource Management, South Dakota State University, Brookings, SD 57007, USA; ${ }^{2}$ Professor, \\ Department of Natural Resource Management, South Dakota State University, West River Agricultural Center, Rapid City, SD 57702, USA; and ${ }^{3}$ former \\ Livestock Educator, currently residing in Aurora, SD 57002, USA.
}

\begin{abstract}
Combined growing- and dormant-season pasture use has potential to increase herbage harvest without causing the undesirable shift in species composition that occurs with excessive utilization. The objective of this study was to determine the effect of summer clipping on winter pastures and winter clipping on summer pastures regarding standing crop, plant community composition, and forage quality. The study was conducted from 2003-2006 at the Antelope and Cottonwood Research Stations located in the mixed-grass prairie of western South Dakota. At each location, the experimental design was a randomized complete block with three replications that included 18 clipping treatments arranged as a split-split plot. Whole plots consisted of four summer clipping dates (May-August). Subplot treatments were two clipping intensities (clipped to residual height to achieve $25 \%$ or $50 \%$ utilization). Sub-subplots consisted of two winter clipping intensities (unharvested or clipped to a residual height to achieve a total utilization of $65 \%$ ). Two winter control treatments were arranged in the subplot and split into two clipping intensities of $50 \%$ and $65 \%$ utilization. Winter biomass for the May 25\% clipping treatment was similar to winter biomass for winter-only clipping. No increase in forage quality resulted from summer clipping compared with winter clipping. Three consecutive yr of combined growing-season and dormant-season defoliation to $65 \%$ utilization resulted in no change in functional group composition compared with $\leq 50 \%$ utilization treatments. Clipping in June resulted in reduced midgrass biomass at both stations and increased shortgrass biomass at Cottonwood. Results suggest that producers could combine growing and dormant-season grazing to increase the harvest of herbage on mixed-grass prairie, but should change season of use periodically to avoid an undesirable shift in plant composition.
\end{abstract}

\section{Resumen}

La combinación en el uso de temporada de crecimiento y dormancia en praderas tiene el potencial de aumentar la cosecha de forraje sin causar el indeseable cambio en la composición de especies que ocurre con la utilización excesiva. El objetivo de este estudio fue determinara el efecto de cortes de verano en praderas de invierno y cortes de invierno en praderas de verano en relación a forraje en pie, composición de las comunidades de plantas y calidad del forraje. El estudio se realizó de 2003 a 2006 en la Estaciones Experimentales de Antelope y Cottonwood ubicadas en la pradera de pastos mixtos en el oeste de South Dakota. En cada lugar, el diseño experimental fue bloques completamente al azar con tres repeticiones que incluían 18 tratamientos de cortes en un arreglo de parcelas y sub-subparcelas divididas. Las parcelas completas consistieron en cuatro fechas de corte de verano (Mayo-Agosto). Los tratamientos de subparcela fueron dos intensidades de corte (cortes con altura residual para lograr el $25 \%$ o $50 \%$ de utilización). Las sub-subparcelas consistieron en dos intensidades de corte en invierno (sin cosecha o corte a altura residual para lograr un $65 \%$ de utilización total). Dos tratamientos testigos fueron arreglados en subparcela y separados en dos intensidades de corte de $50 \%$ y $65 \%$ de utilización). La biomasa de invierno para el tratamiento del $25 \%$ de Mayo fue similar a la biomasa de invierno para los cortes solo de invierno. No hubo aumento en la calidad del forraje de los cortes de verano comparado con los cortes de invierno. La combinación de tres años consecutivos de defoliación en temporada de crecimiento y dormancia al $65 \%$ de utilización resultaron en ningún cambio en la funcionalidad de la composición del grupo comparado con $\leq 50 \%$ de tratamientos de utilización. Los cortes en Junio resultaron en reducción de biomasa de pastos medianos en ambas estaciones y aumento en la biomasa de pastos cortos en Cottonwood. Los resultados sugieren que los productores podrán combinar el pastoreo en temporadas de crecimiento y dormancia para aumentar la cosecha de forraje en praderas mixtas, pero deberán cambiar temporadas de uso periódicamente para evitar cambios no deseados en la composición de plantas.

Key Words: clipping, dormant season, growing season, utilization

\section{INTRODUCTION}

Sustainable strategies to increase harvest efficiency could provide important economic benefits to ranch operations worldwide. Harvest efficiency (i.e., proportion of annual forage

Correspondence: Alexander J. Smart, Dept of Natural Resource Management, South Dakota State University, Animal Science Complex, 1029 North Campus Drive, Brookings, SD 57007, USA. Email: Alexander.smart@sdstate.edu

Manuscript received 9 September 2011; manuscript accepted 8 June 2012. produced that is consumed by livestock; see Smart et al. 2010) can be increased in two, often interrelated, ways. One is to increase the proportion of forage ingested; studies indicate this can be accomplished through grazing systems (Heitschmidt et al. 1982) and/or it occurs on pastures with long-term heavy stocking histories (Smart et al. 2010). The second is to increase overall utilization while at least maintaining the proportion of forage ingested. This option might be problematic because many studies have demonstrated that grazing strategies that increase the amount of forage removed from rangelands can 
lead to undesirable species composition changes, increased soil bulk density, increased runoff of water and sediment, reduced soil cover, reduced infiltration, and/or increased weedy forbs and woody plant species (Rauzi and Hanson 1966; McCalla et al. 1984; Dormaar and Willms 1998; Archer 1999; Lauenroth et al. 1999; Miller et al. 1999). These factors, and others, commonly result in less productive vegetation, reduced individual animal production, and potentially, a reduction in the ability of a ranch to generate wealth (Mcllvain and Shoop 1961; Vallentine 1990; Lauenroth et al. 1999; Holechek et al. 2001).

Much of the research on the consequences of increased utilization has focused on grazing during the growing season. In the Great Plains, however, where winter snow cover is intermittent, producers typically set aside separate pastures for summer and winter grazing. Summer pastures are grazed during the growing season when higher levels of utilization $(>60 \%)$ are most likely to result in undesirable shifts in species composition and reductions in total production. Winter pastures, however, are grazed almost exclusively during the dormant season. Grazing in the dormant season removes plant tissue that is not photosynthetically active and thus does not disrupt growing-season plant functions. These two types of seasonal-use pastures provide an opportunity to increase utilization of rangelands in the northern Great Plains by 1) grazing winter pastures lightly in summer and 2) grazing summer pastures in winter.

It is reasonable to expect that winter pastures could be grazed during the growing season without altering plant community composition if utilization is light; however, the extent to which summer grazing would alter total winter standing crop is unclear. It is possible that compensatory growth (McNaughton 1979; Briske and Richards 1994) could result in little or no reduction in winter standing crop. In addition, regrowth occurring as a result of summer clipping would be expected to increase the quality of the forage compared to vegetation unclipped during summer (Anderson and Scherzinger 1975). It also might be expected that undesirable shifts in species composition associated with higher levels of growing-season utilization $(>60 \%$ ) (see Hart and Balla 1982; Smart et al. 2007) would not occur on summer pastures if the additional grazing occurred during the dormant season. It is possible that a reduction in soil moisture might occur if dormant-season grazing reduces litter and standing dead material. In an extreme case, Willms et al. (1986) removed all the litter and standing dead vegetation from plots during the dormant season in mixed-grass prairie and fescue prairie in southern Alberta, Canada; they showed a $43 \%$ reduction in herbage production compared with the control at the mixed-grass site but saw no effect at the fescue site after 3 treatment yr. They speculated that the more xeric mixed-grass prairie site was more susceptible to moisture stress from reduced litter, whereas the litter at the more mesic fescue prairie site had actually inhibited growth (Willms et al. 1986).

The separate summer and winter pastures common in the Great Plains provide an opportunity for producers to increase their harvest efficiency by strategically utilizing both growingseason and dormant-season defoliation on both types of pastures. The objective of this study, then, was to determine the effect of spring/summer defoliation on winter pastures and winter defoliation on summer pastures, regarding standing crop, plant community composition, and forage quality. Hypotheses for this study were: 1) clipping early in the growing season at a low intensity will result in no loss in total winter standing herbage compared to winter clipping alone, 2) forage quality of winter standing herbage will be improved by summer clipping compared to winter clipping alone, and 3) combining growing-season and dormant-season clipping (total utilization $>60 \%$ ) will not cause the undesirable shift in species composition expected with heavy growing-season use, as long no more than $50 \%$ of the utilization comes during the growing season.

In order to test the viability of these defoliation strategies, we devised a clipping study to evaluate 1) the influence of the timing and intensity of summer clipping on winter herbage biomass and forage quality compared with winter-only clipping and 2) the 3-yr cumulative effects of yearly summer and/or winter clipping intensity on herbage biomass and functional group composition.

\section{MATERIALS AND METHODS}

\section{Site Description}

This study was conducted from 2003-2006 on northern Great Plains mixed-grass rangeland at South Dakota State University's Antelope and Cottonwood Range and Livestock Research Stations near Buffalo, South Dakota (lat $45^{\circ} 32.96^{\prime} \mathrm{N}$, long $103^{\circ} 19.69^{\prime} \mathrm{W}$ ) and near Cottonwood, South Dakota (lat $43^{\circ} 58.08^{\prime} \mathrm{N}$, long $\left.101^{\circ} 51.62^{\prime} \mathrm{W}\right)$, respectively. The climate of both stations is continental and semiarid, with hot summers and cold winters. Average annual precipitation from 1971 to 2000 at Redig, South Dakota (30 km SW of Antelope Station) and Cottonwood was approximately $395 \mathrm{~mm}$ and $440 \mathrm{~mm}$, respectively, $75 \%$ of which falls from April to September (High Plains Regional Climate Center 2011). Mean daily temperature for the Antelope and Cottonwood study areas was $6.2^{\circ} \mathrm{C}$ and $8.2^{\circ} \mathrm{C}$ with a high of $42^{\circ} \mathrm{C}$ and $47^{\circ} \mathrm{C}$ in July and a low of $-39^{\circ} \mathrm{C}$ and $-41^{\circ} \mathrm{C}$ in January, respectively (High Plains Regional Climate Center 2011). At Antelope, the elevation of the experimental site is $880 \mathrm{~m}$ above sea level; soil is a Gerdrum silt loam (Fine, montmorillonitic, frigid Typic Natriboralfs) with $0 \%$ slope, and the site is classified as a Claypan ecological site R058DY0138SD (Soil Survey Staff 2011). At Cottonwood, the elevation of the experimental site is $730 \mathrm{~m}$ above sea level; soil is Kyle clay (Very-fine, montmorillonitic, mesic Aridic Haplusterts) with $6 \%$ slope, and the site is classified as a Clayey ecological site R063AY011SD (Soil Survey Staff 2011). Vegetation at the stations is typical of mixed-grass prairie. Dominant species include western wheatgrass (Pascopyrum smithii [Rydb.] Á. Löve), a cool-season $\left(\mathrm{C}_{3}\right)$ midgrass, and blue grama (Bouteloua gracilis [Knuth] Lag. ex Griffiths) and buffalograss (Buchloe dactyloides [Nutt.] Engelm.), which are warm-season $\left(\mathrm{C}_{4}\right)$ shortgrasses (Stubbendieck et al. 1992). Less dominant species include green needlegrass (Nassella viridula [Trin.] Barkworth), prairie junegrass (Koeleria macrantha [Ledeb.] Schult.), sedges (Carex spp), and a variety of native forbs. Kentucky bluegrass (Poa pratensis L.) was present in the plant communities at both locations. Both study sites had been 
Table 1. Western wheatgrass plant height and cutting heights to achieve $25 \%$ and $50 \%$ utilization at four summer cutting dates at Antelope (near Buffalo, South Dakota) and Cottonwood (near Cottonwood, South Dakota) research stations from 2003 to 2005.

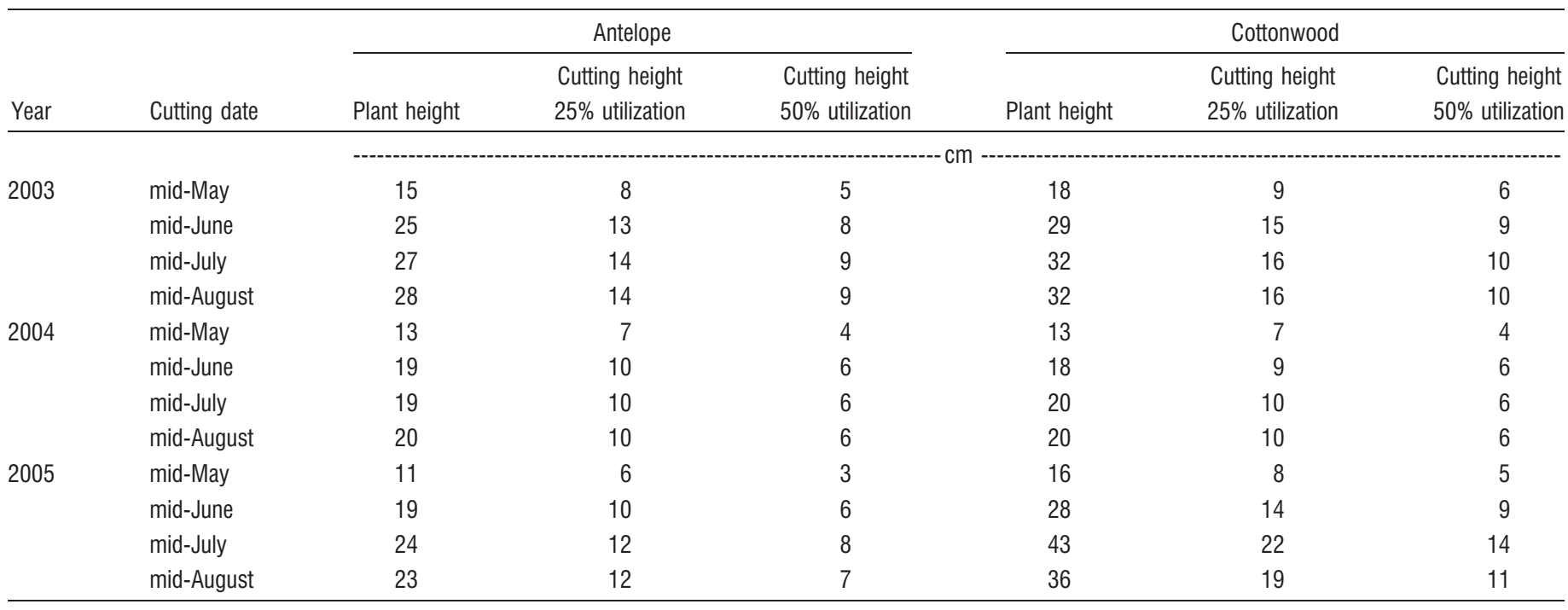

protected from grazing for several years prior to the initiation of this study.

\section{Experimental Design}

At each research station the experimental design was a randomized complete block design with three replications and 18 clipping treatments $(4 \times 2 \times 2$ factorial augmented with two control treatments) arranged as a split-split plot (Steel and Torrie, 1980). The whole-plot $(4 \times 8 \mathrm{~m})$ treatments included four summer clipping dates (mid-May, mid-June, mid-July, and mid-August). Subplot $(2 \times 8 \mathrm{~m})$ treatments were two summer clipping intensities (clipped to residual height to achieve 25\% or $50 \%$ utilization of western wheatgrass) applied to the summer clipping date whole plots. Subsubplot $(2 \times 4 \mathrm{~m})$ treatments were two winter clipping intensities (unclipped or clipped to a residual height to achieve $65 \%$ total utilization [= summer + winter utilization]) applied to the summer clipping subplots. The two winter control treatments were arranged in the subplot $(2 \times 8 \mathrm{~m})$ and split into two winter clipping intensities of $50 \%$ and $65 \%$ utilization $(2 \times 4 \mathrm{~m})$.

\section{Clipping Treatment Application}

In 2003, the summer clipping dates at Antelope occurred on 14 May, 13 June, 14 July, and 12 August, and at Cottonwood on 15 May, 13 June, 13 July, and 13 August. In 2004, the summer clipping dates at Antelope occurred on 17 May, 17 June, 15 July, and 13 August, and at Cottonwood on 17 May, 17 June, 14 July, and 12 August. In 2005, the summer clipping dates at Antelope occurred on 16 May, 14 June, 13 July, and 15 August, and at Cottonwood on 17 May, 14 June, 13 July, and 16 August.

Clipping height to achieve 25 or $50 \%$ utilization at each summer clipping date was determined by the plant height/ weight relationship of western wheatgrass using the following equation (P. Johnson, unpublished results, 2001):

$$
\mathrm{W}=-3.85105+2.020275 \times \mathrm{H}-0.00959 \times \mathrm{H}^{2}
$$

where $\mathrm{H}$ is the percent of height remaining in stubble and $\mathrm{W}$ is the percent of weight in remaining stubble. Twenty-five random western wheatgrass tiller heights were measured from the soil surface to the tip of the highest extended leaf in each plot just prior to the application of a summer clipping treatment. Average plant height was calculated and clipping height was calculated using Equations [2] and [3] which were derived from Equation [1]:

$$
\mathrm{S}_{25}=\mathrm{P} \times 0.515
$$

where $\mathrm{P}$ is the average plant height and $\mathrm{S}_{25}$ is the stubble height remaining to achieve $25 \%$ utilization.

$$
\mathrm{S}_{50}=\mathrm{P} \times 0.315
$$

where $\mathrm{P}$ is the average plant height and $\mathrm{S}_{50}$ is the stubble height remaining to achieve $50 \%$ utilization. Plots were clipped to the specified stubble height (Table 1) using a sickle-bar mower and lightly raked to remove clipped vegetation with minimal disturbance to existing litter. In winter 2003-2004, plots were clipped on 1 April 2004 at Antelope (early winter snow fall that remained most of the winter precluded clipping at earlier dates) and on 23 December 2003 at Cottonwood. In winter 20042005, plots were clipped on 4 December 2004 at Antelope and 11 December 2004 at Cottonwood. In winter 2005-2006, plots were clipped on 4 February 2006 at Antelope and 28 January 2006 at Cottonwood. Plant height for each plot was estimated by measuring 25 random western wheatgrass tillers from the soil surface to the highest extended leaf. If average winter plant height was less than the plant height measured in the summer (little to no regrowth), then the clipping height to achieve a total utilization of $65 \%$ was based on summer plant height. Otherwise the winter plant height was used to estimate the clipping height to achieve $65 \%$ total utilization. Equation [4] was used to determine stubble height to achieve $65 \%$ utilization.

$$
\mathrm{S}_{65}=\mathrm{P} \times 0.215
$$

where $\mathrm{P}$ is the average plant height and $\mathrm{S}_{65}$ is the stubble height remaining to achieve $65 \%$ utilization. 


\section{Biomass Estimates}

Immediately prior to the winter defoliation treatments each year and at the end of the study (August 2006), aboveground biomass was subsampled using one $0.25 \mathrm{~m}^{2}$ quadrat placed within the experimental unit, avoiding quadrat locations from previous biomass clippings. Samples were hand clipped to ground level, dried in a forced air oven at $60^{\circ} \mathrm{C}$ for $72 \mathrm{hr}$, and weighed. Samples were then separated into five categories: current year midgrasses, shortgrasses, cheatgrass (Bromus spp.), and forbs, and previous years' standing dead. Litter was not sampled. Total biomass was the sum of midgrasses, shortgrasses, cheatgrass, and forbs. Plots were not disturbed in summer 2006, so August 2006 estimates represent the growth potential of treatments following $3 \mathrm{yr}$ of clipping.

\section{Forage Quality Analysis}

Forage samples (previously sorted into midgrass, shortgrass, cheatgrass, and forbs) from winters 2003-2004 and 20042005 were recombined into total herbage based on whole plot and subplot treatments because of limitations in sample amounts. Samples were ground with a Wiley mill (Arthur Thomas Co., Philadelphia, PA) to pass through a 1-mm screen and stored in plastic bags at room temperature prior to wet chemistry analysis. Procedures described by Goering and Van Soest (1970) and modified by Undersander et al. (1993) were used to determine acid detergent fiber (ADF) and neutral detergent fiber (NDF). Crude protein (CP) concentration was determined by the macro-Kjeldahl method (AOAC 1990). A subsample was used to determine dry matter (DM) content (AOAC 1990); ADF, NDF, and CP were corrected to $100 \%$ DM.

\section{Statistical Analysis}

Due to restrictions on randomization of the split-split plot design with the augmented controls, summer clipping dates at $25 \%$ utilization and the winter-only clipping treatment were analyzed for winter biomass, CP, NDF, and ADF using PROC MIXED of SAS (2006). The model included fixed effects of site, date, year, and their interactions. Block within site, date-by-block within site, and the residual were considered random effects. Year was considered a repeated measure and analyzed as a split in time (Steel and Torrie 1980), which adequately accounted for error correlation among years. Linear and quadratic contrasts were tested for summer clipping date using the CONTRAST and ESTIMATE statements.

Final treatment response biomass estimates in 2006 were analyzed from the summer clipping dates at $50 \%$ utilization and split-split plots of combined summer and winter utilization $(50 \%$ or $65 \%)$ and the two winter control treatments of $50 \%$ and $65 \%$ utilization. These biomass estimates were analyzed using PROC MIXED of SAS (2006). Site, date, utilization $(50 \%$ or $65 \%)$, and their interactions were considered fixed effects. Block within site, date-by-block within site, and residual were considered random effects. All means were computed using the LSMEANS statement and separated using the PDIFF option. Means were considered different at $P<0.05$.

\section{RESULTS}

\section{Winter Biomass}

Winter biomass is the standing crop produced the previous growing season minus any biomass removed by a clipping treatment. It allows us to evaluate the relative effects of different clipping dates and levels on subsequent production. If winter biomass for a summer clipping treatment is similar to the winter-only clipping treatment, one could surmise that the clipping treatment did not adversely reduce the amount of forage available for winter use.

Total Winter Biomass. Clipping date-by-year $(P=0.03)$ and site-by-year $(P<0.01)$ interactions were evident for total winter biomass. Total winter biomass for the May clipping treatment (sites combined) was similar to total winter biomass for the winter-only clipping treatment for the same year in 2003 and 2004, but not 2005 (Fig. 1a). Clipping later in the summer, however, generally reduced total winter standing biomass compared to the winter-only clip control within the same year for all $3 \mathrm{yr}$ (Fig. 1a) with the exception of June 2004. In that case, June 2004 clipping resulted in similar total winter biomass compared to the winter-only clipping treatment. Spring precipitation, an important driver in forage production (Smart et al. 2007), was considerably lower at both stations (Table 2) in $2004(39 \%$ and $50 \%$ of long-term average for Antelope and Cottonwood, respectively) than in both 2003 (57\% and $76 \%$, respectively) and $2005(86 \%$ and $132 \%$, respectively), which may help explain the overall reduced biomass (Table 3) and very limited response to treatments in 2004. Greatest winter biomass (Table 3) occurred in 2005 at Cottonwood, associated with a wetter than average spring (126\% of long-term average) and in 2003 at Antelope, near the beginning of the extended drought period. Summer clipping dates led to a linear decrease in total biomass in 2003 $(P<0.01)$ and $2005(P<0.04)$, but not in $2004(P<0.49)$. These data suggest that, in some years, winter pastures can be grazed in May (at least up to $25 \%$ biomass removal) without significantly reducing total standing crop available the following winter; however, defoliation in other growing-season months is almost always detrimental to total winter biomass availability.

Winter Midgrass Biomass. Winter midgrass biomass had a clipping date-by-year $(P=0.02)$ and site-by-year $(P<0.01)$ interaction. Midgrasses make up the majority of the biomass at both research sites; thus, it is not surprising that responses for winter midgrass biomass were very similar to those of total winter biomass. Winter midgrass biomass for the May clipping treatment (sites combined) was similar to winter midgrass biomass of the winter-only clipping treatment for the same year in 2003 and 2004, but not 2005 (Fig. 1b). Clipping later in the summer, however, reduced winter midgrass standing biomass compared to the winter-only clip control within the same year for 2003 and 2005, but not for 2004 where there were no differences between any of the clipping treatments (Fig. 1b). Winter midgrass biomass decreased linearly with later summer clipping dates in $2003(P<0.01)$, but the slope was not different from zero in $2004(P<0.46)$ and in $2005(P<0.13)$. Midgrass biomass was lowest in 2004 for both sites and 

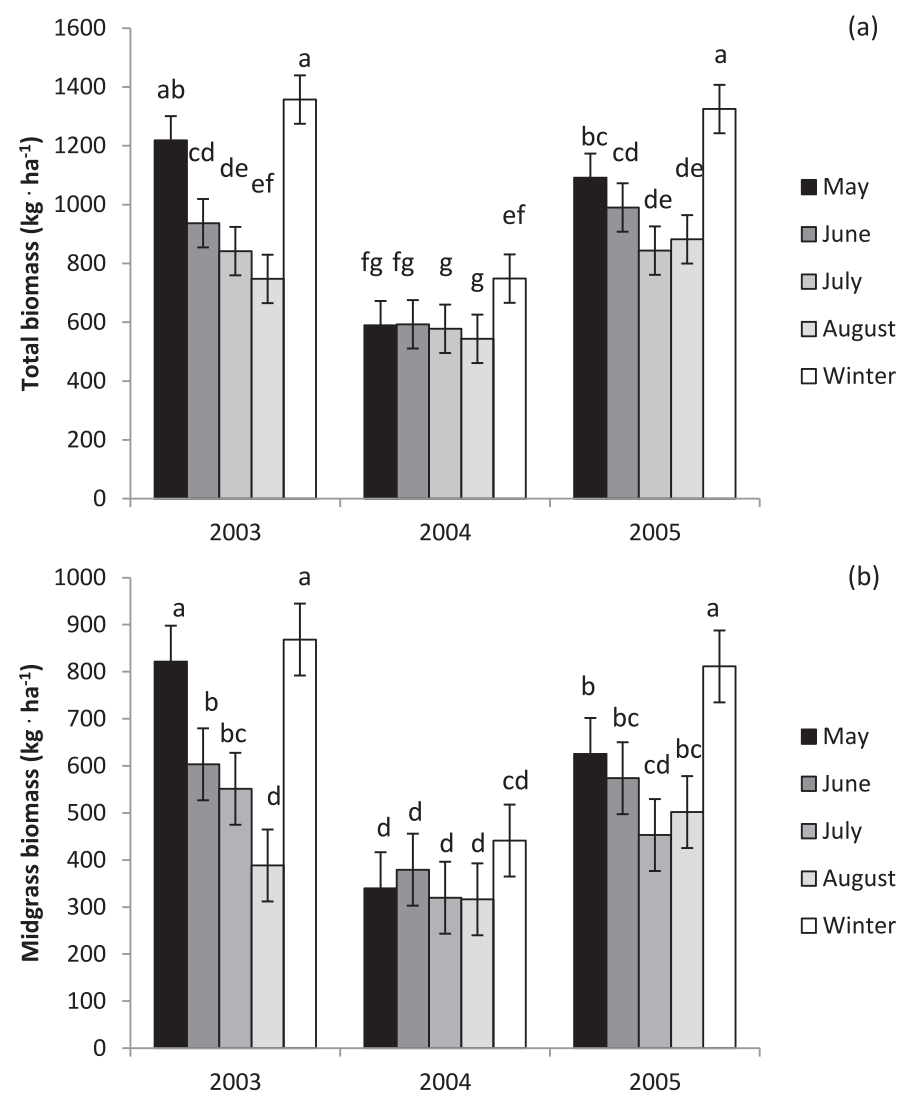

(b)

- May

口June

$\square$ July

$\square$ August

$\square$ Winter

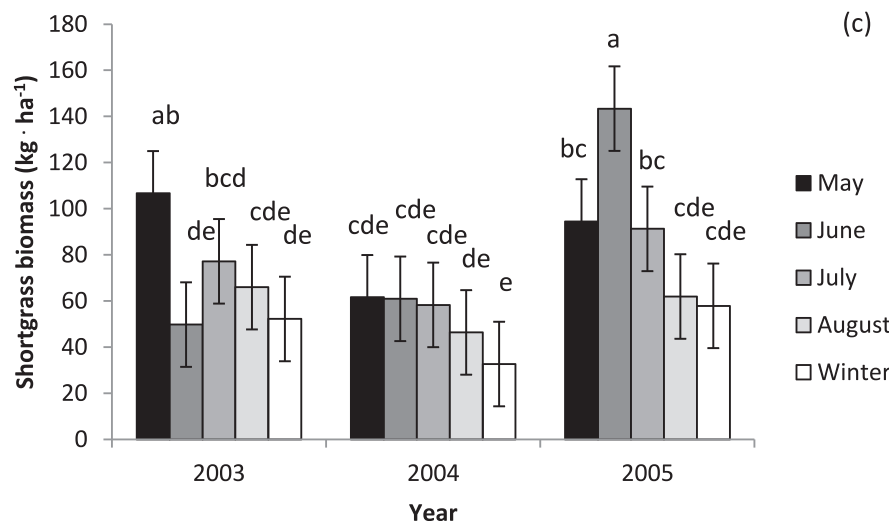

Figure 1. The interaction of clipping date (mid-May, mid-June, mid-July, and mid-August, and winter) and year (2003, 2004, and 2005) on winter standing a, total, b, midgrass, and c, shortgrass biomass averaged over two research sites in western South Dakota. Bars having the same letter(s) are not different $(P \geq 0.05)$.

greatest in 2005 at Cottonwood and at Antelope in 2003 (Table $3)$.

Winter Shortgrass Biomass. Clipping date-by-year $(P=0.05)$ and site-by-year $(P<0.01)$ interactions were evident for winter shortgrass biomass. Winter shortgrass biomass was greatest for the May 2003 and June 2005 clipping dates (Fig. 1c); however, it appears that clipping in any month of the growing season results in winter shortgrass biomass that is at least equal to, and in several cases greater than, winter shortgrass biomass on winter-clipped plots. No linear or quadratic relationship existed among summer clipping dates in 2003 or 2004, but there was a quadratic tendency $(P<0.06)$ in 2005 . Shortgrass biomass tended to be the lowest for August and winter clipping dates, except in the drought year of 2004. Shortgrass biomass was greatest for Cottonwood in 2005 and least for Antelope in 2004 (Table 3).

Winter Cheatgrass Biomass. There was a site-by-year-byclipping date interaction $(P=0.02)$ for winter cheatgrass biomass. At Antelope there were no differences among any clipping dates and years in cheatgrass biomass (Fig. 2). At Cottonwood, June, July, and August clipping reduced cheatgrass biomass compared with winter clipping in 2003 and 2005 (Fig. 2). In 2004, all clipping treatments had similar cheatgrass biomass. This is likely related to the relative availability of spring moisture, which was extremely limited in 2004 (48\% of long-term average, Table 2) compared to 2003 (73\%) and 2005 $(126 \%)$.

Winter Forb Biomass. Year $(P=0.03)$ and site $(P=0.04)$ main effects were observed for winter forb biomass. Forb biomass was $30 \mathrm{~kg}, 11 \mathrm{~kg}$, and $57 \mathrm{~kg} \cdot \mathrm{ha}^{-1}$ for 2003, 2004, and 2005 , respectively $\left(P<0.05 ; \mathrm{SE}=5.2 \mathrm{~kg} \cdot \mathrm{ha}^{-1}\right)$. Forb biomass at Antelope $\left(24 \mathrm{~kg} \cdot \mathrm{ha}^{-1}\right)$ was lower $(P<0.05)$ than Cottonwood $\left(42 \mathrm{~kg} \cdot \mathrm{ha}^{-1}\right)$.

Standing Dead Biomass. There was a site-by-year interaction for standing dead biomass $(P<0.01)$. Both Antelope and Cottonwood had the greatest winter standing dead biomass in 2003, which then decreased dramatically in 2004 and remained low in 2005 (Table 3). In 2004 and 2005, winter standing dead biomass was similar for both research sites (Table 3). There was no summer clipping date treatment effect $(P=0.30)$ on winter standing dead biomass.

\section{Winter Forage Quality}

There was a site-by-year $(P<0.01)$ interaction, but no clipping date effect on winter herbage $\mathrm{CP}(P=0.18)$, NDF $(P=0.21)$, or ADF $(P=0.51)$ concentration. Winter herbage CP concentration was greater for both years at Antelope than at Cottonwood and greater in 2004 than in 2003 at both stations (Table 4). Winter herbage NDF concentration did not differ between years at Antelope, but was greater in 2003 than 2004 at Cottonwood (Table 4). Winter herbage ADF concentration declined from 2003 to 2004 at both stations, with the greatest decline occurring at Cottonwood (Table 4).

\section{End of Study Effects-Final Treatment Response (FTR) Biomass}

Standing biomass was harvested in August 2006 to evaluate the cumulative effects of $3 \mathrm{yr}$ of summer and winter clipping. Total FTR biomass (sum of midgrasses, shortgrasses, cheatgrass, and forbs) at Cottonwood $\left(1373 \mathrm{~kg} \cdot \mathrm{ha}^{-1)}\right.$ was greater $(P=0.02)$ than at Antelope $\left(932 \mathrm{~kg} \cdot \mathrm{ha}^{-1}\right)$. Three yr of June clipping resulted a lower $(P=0.03)$ midgrass FTR biomass compared to all months except August (Fig. 3). Three yr of May, July, August, or winter clipping produced similar midgrass FTR biomass (Fig. 3). A site-by-date $(P=0.03)$ interaction for shortgrass FTR biomass was detected. Clipping treatments had very little effect on shortgrass FTR biomass at Antelope (Fig. 4a). The June clipping treatment produced greater shortgrass FTR biomass than the August clipping; however, 
Table 2. Seasonal and the 30-yr mean (1971-2000) precipitation for Redig, South Dakota (30 km southwest of the Antelope Research Station) and the Cottonwood Research Station (near Cottonwood, South Dakota), 2003 to 2006.

\begin{tabular}{|c|c|c|c|c|c|c|c|c|c|c|}
\hline \multirow[b]{2}{*}{ Period } & \multicolumn{5}{|c|}{ Antelope } & \multicolumn{5}{|c|}{ Cottonwood } \\
\hline & 2003 & 2004 & 2005 & 2006 & 30-yr mean & 2003 & 2004 & 2005 & 2006 & 30-yr mean \\
\hline & ---- & 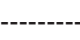 & - & -- & 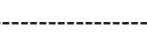 & ---- & -1 & & & \\
\hline Winter $^{1}$ & 89 & 46 & 16 & 35 & 47 & 48 & 43 & 41 & 84 & 61 \\
\hline Spring $^{2}$ & 110 & 75 & 166 & 153 & 193 & 143 & 93 & 245 & 87 & 195 \\
\hline Summer ${ }^{3}$ & 48 & 195 & 71 & 61 & 89 & 68 & 23 & 48 & 49 & 134 \\
\hline Autumn ${ }^{4}$ & 124 & 77 & 75 & 53 & 73 & 67 & 142 & 53 & 80 & 78 \\
\hline Annual & 380 & 383 & 340 & 288 & 395 & 280 & 325 & 409 & 312 & 433 \\
\hline
\end{tabular}

${ }^{1}$ Winter includes December of previous year and January-March of current year.

${ }^{2}$ Spring includes April-June.

${ }^{3}$ Summer includes July-August.

${ }^{4}$ Autumn includes September-November.

shortgrass FTR biomass for the May, July, August, and winter clipping treatments were similar. The more dramatic response occurred at Cottonwood, where the June clipping treatment resulted in greater shortgrass FTR biomass than any of the other clipping treatments. May, July, August, and winter clipping treatments yielded similar shortgrass FTR biomass. A date-by-site $(P=0.02)$ interaction for cheatgrass FTR biomass also was observed (Fig. 4b). At Antelope, all clipping treatments resulted in similar cheatgrass FTR biomass. At Cottonwood, however, August and July clipping treatments produced greater cheatgrass FTR biomass than each of the other clipping treatments. No clipping date, utilization, or site main effects for forb biomass or standing dead were observed.

\section{DISCUSSION}

Clipping is a useful and economical technique to investigate plant responses to defoliation at small scales, but has limitations as a surrogate for grazing. Grazing animals 1 ) tend to pull and tear leaves and stems rather than cleanly sever them, 2 ) trample vegetation, 3) rarely graze evenly unless at very high grazing pressures, and 4) return nutrients, compared to clipping (Heady and Child, 1994; Wallace 1990). In clipping studies, defoliation tends to be more severe because herbage is removed from every tiller taller than the clip height, which is unrealistic under grazing situations (Wallace 1990). Our study was no exception. We observed that clipping to achieve $25 \%$ or $50 \%$ utilization of western wheatgrass (Table 1) removed very little herbage from shortgrass species. We recognize that western wheatgrass received more severe use than the shortgrass species such as blue grama, buffalograss, and sedges. Zhang and Romo (1994), using the same mowing technique, also observed that low sedges escaped defoliation at a clipping height of $5 \mathrm{~cm}$. In spite of the limitations, clipping studies provide an excellent opportunity to better understand the impacts of timing and severity of defoliation on plant responses. Such studies are particularly useful in identifying treatments of potential value in subsequent grazing studies.

The results of this clipping study supported our hypothesis that clipping early in the growing season and at a low intensity allows adequate regrowth so that total winter standing herbage is comparable to treatments clipped only during winter. Winter total, midgrass, and shortgrass herbage from May clipping, at $25 \%$ utilization, was similar to winter clipping 2 out of $3 \mathrm{yr}$ and provides evidence of compensatory growth (McNaughton 1979; Briske and Richards 1994). In a similar study, Holderman and Goetz (1981) harvested mixed grass prairie at two locations in western North Dakota from late May until midJuly to a stubble height of $2.5 \mathrm{~cm}$. They found the combined

Table 3. Site-by-year interaction for winter standing biomass at Antelope (near Buffalo, South Dakota) and Cottonwood (near Cottonwood, South Dakota) research stations averaged across four clipping dates (mid-May, mid-June, mid-July, and mid-August) for 2003, 2004, and 2005.

\begin{tabular}{|c|c|c|c|c|c|c|c|}
\hline Site & Year & Total $^{1}$ & Midgrass $^{2}$ & Shortgrass ${ }^{3}$ & Cheatgrass & Forbs & Standing dead \\
\hline Antelope & 2003 & $800 c^{4}$ & $650 \mathrm{~b}$ & $79 \mathrm{~b}$ & $60 d$ & 12 & $333 \mathrm{a}$ \\
\hline Antelope & 2004 & $496 \mathrm{e}$ & $328 d$ & $33 \mathrm{c}$ & $121 \mathrm{c}$ & 15 & $38 \mathrm{c}$ \\
\hline Antelope & 2005 & $626 \mathrm{~d}$ & $437 \mathrm{c}$ & $66 \mathrm{~b}$ & $84 \mathrm{~cd}$ & 40 & $33 \mathrm{c}$ \\
\hline Cottonwood & 2003 & $1241 \mathrm{~b}$ & $644 \mathrm{~b}$ & $62 \mathrm{~b}$ & $484 \mathrm{a}$ & 51 & $172 \mathrm{~b}$ \\
\hline Cottonwood & 2004 & $724 \mathrm{c}$ & $391 \mathrm{~cd}$ & $71 \mathrm{~b}$ & $226 \mathrm{~b}$ & 36 & $25 \mathrm{c}$ \\
\hline \multirow[t]{3}{*}{ Cottonwood } & 2005 & $1426 \mathrm{a}$ & $749 a$ & $113 \mathrm{a}$ & $475 \mathrm{a}$ & 88 & $61 \mathrm{c}$ \\
\hline & SE & 52.0 & 48.3 & 12.4 & 19.5 & 15.1 & 25.0 \\
\hline & $P$ value & $<0.01$ & $<0.01$ & $<0.01$ & $<0.01$ & 0.78 & $<0.01$ \\
\hline
\end{tabular}

${ }^{1}$ Total includes the sum of biomass from midgrass, shortgrass, cheatgrass, and forbs.

${ }^{2}$ Midgrass includes western wheatgrass, green needlegrass, prairie junegrass, and Kentucky bluegrass.

${ }^{3}$ Shortgrass includes blue grama, buffalograss, and sedges.

${ }^{4}$ Means within a column followed by different letters are statistically different $(P<0.05)$. 


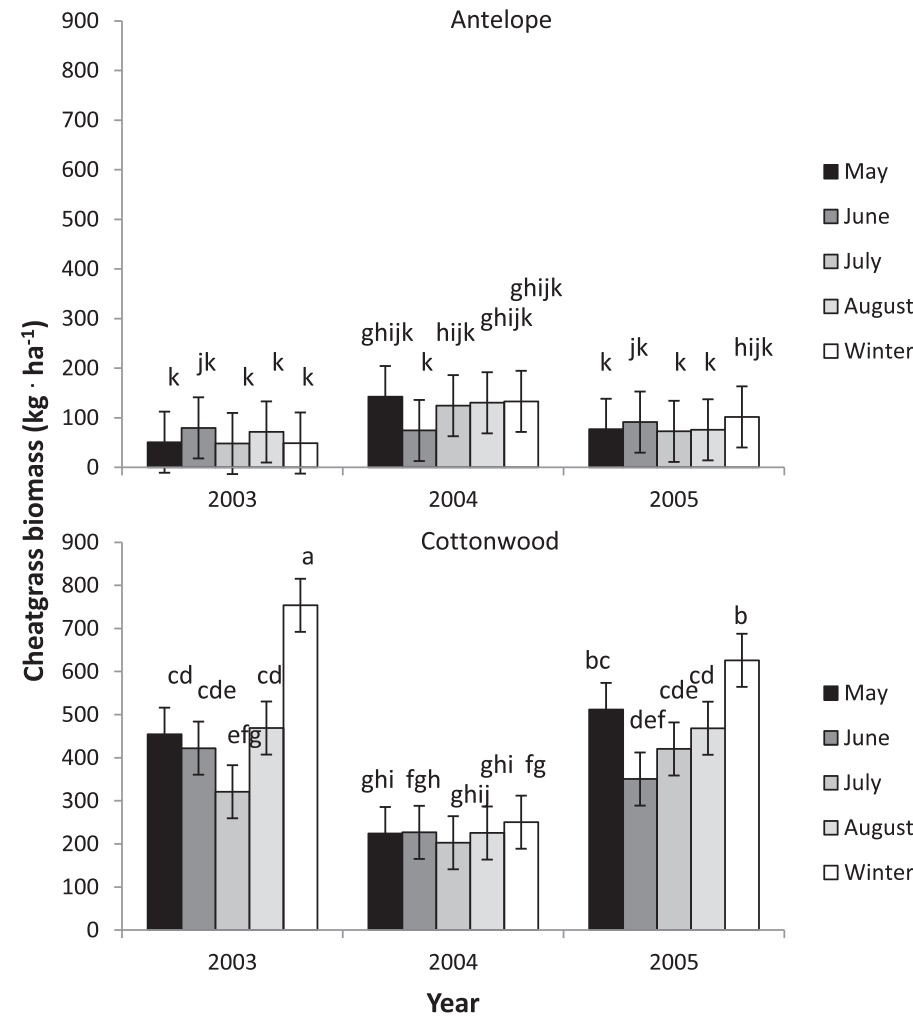

Figure 2. The interaction of site (Antelope near Buffalo, South Dakota and Cottonwood, near Cottonwood, South Dakota), clipping date (mid-May, mid-June, mid-July, mid-August, and winter), and year (2003, 2004, and $2005)$ on winter cheatgrass biomass. Bars having the same letter(s) are not different $(P \geq 0.05)$.

production (biomass removed earlier in the summer plus the residual remaining in fall) of western wheatgrass was greater than the unharvested control for late May and early June clipping dates in $1 \mathrm{yr}$ out of 2 . Summer biomass from the early July clipping date tended to be the peak and was greater than the control (Holderman and Goetz 1981). Zhang and Romo (1994) showed that repeated clipping of northern wheatgrass (Elymus lanceolatus [Scribn. \& J.G. Sm.] Gould subsp. lanceolatus) every 2 or $6 \mathrm{wk}$ from initial clipping dates in May, June, July, or August produced total live plant material (summer plus winter biomass) similar to control in 2 out of 3

Table 4. Effect of site-by-year interaction for crude protein (CP), neutral detergent fiber (NDF), and acid detergent fiber (ADF) of winter herbage at Antelope (near Buffalo, South Dakota) and Cottonwood (near Cottonwood, South Dakota) research stations averaged over four summer clipping dates (mid-May, mid-June, mid-July, and mid-August) for 2003 and 2004.

\begin{tabular}{|c|c|c|c|c|}
\hline Site & Year & $\mathrm{CP}$ & NDF & ADF \\
\hline & & \multicolumn{3}{|c|}{ - } \\
\hline Antelope & 2003 & $4.7 \mathrm{~b}^{1}$ & $73.1 \mathrm{a}$ & $40.7 b$ \\
\hline Antelope & 2004 & $6.9 \mathrm{a}$ & $72.8 a b$ & $39.0 \mathrm{c}$ \\
\hline Cottonwood & 2003 & $3.5 d$ & $75.2 \mathrm{a}$ & $42.3 \mathrm{a}$ \\
\hline Cottonwood & 2004 & $4.1 \mathrm{C}$ & $70.6 \mathrm{~b}$ & 38.10 \\
\hline SE & & 0.15 & 0.84 & 0.52 \\
\hline$P$ value & & $<0.01$ & $<0.01$ & $<0.01$ \\
\hline
\end{tabular}

${ }^{1}$ Means within a column followed by different letters are statistically different $(P<0.05)$.

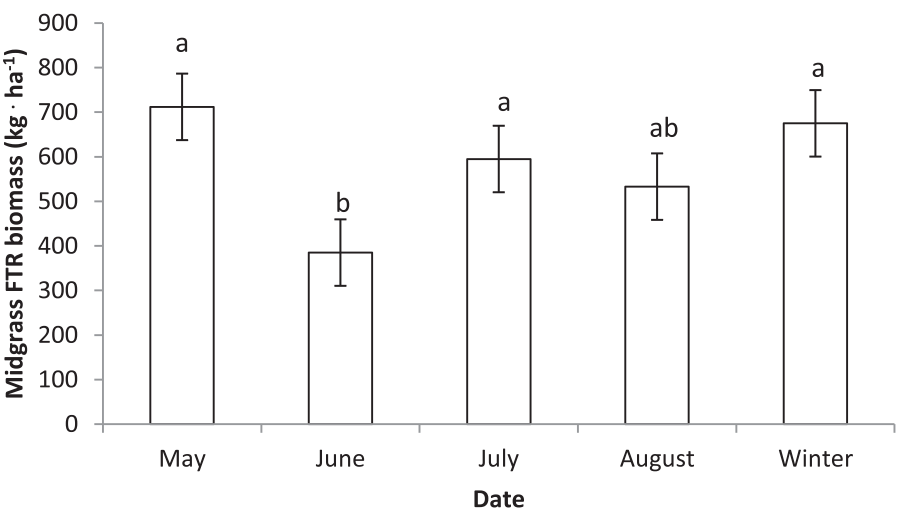

Figure 3. The effect of clipping date (mid-May, mid-June, mid-July, midAugust, and Winter) on final treatment response (FTR) midgrass biomass measured August 2006 following 3 yr of clipping treatments, averaged over two research sites in western South Dakota. Bars having the same letter(s) are not different $(P \geq 0.05)$.

yr. Hart and Balla (1982) showed that western wheatgrass tillers, under light stocking, had increased weight per tiller compared to ungrazed tillers. Although our study and others suggest that plants might respond to defoliation during the growing season with compensatory growth, it appears that losses due to senescence do not trigger a similar response. For example, Sims and Singh (1978) determined that losses from
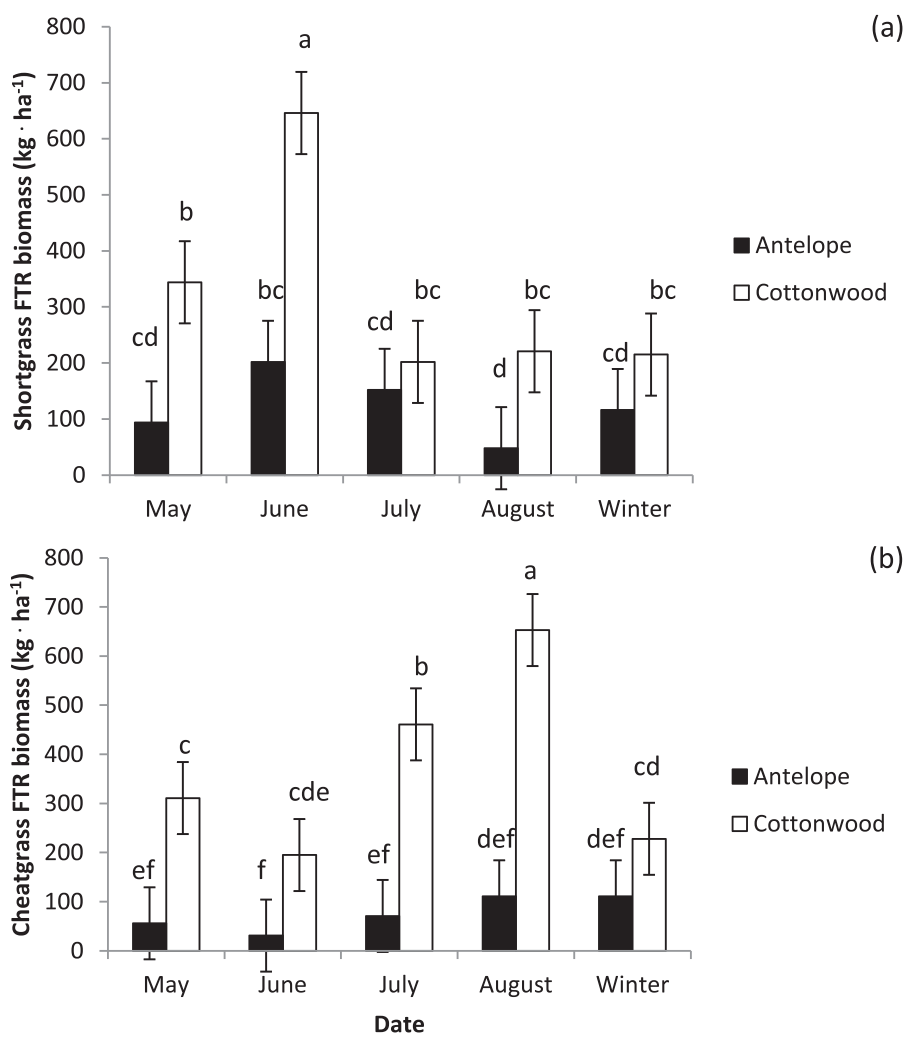

Figure 4. The interaction of site (Antelope near Buffalo, South Dakota and Cottonwood near Cottonwood, South Dakota) and clipping date (mid-May, mid-June, mid-July, mid-August, and winter) on final treatment response (FTR) a, shortgrass, and $\mathbf{b}$, cheatgrass biomass measured in August 2006. Bars having the same letter(s) are not different $(P \geq 0.05)$. 
senesced leaves at the onset of plant maturity or dry weather could result in lower yield measured at the end of the season compared to mid- to late-summer biomass.

Regardless of the mechanism by which western wheatgrass responds to early summer defoliation with similar or more biomass production, this response has important implications for harvest efficiency. Had we measured herbage biomass removed during summer clipping and summed that with residual winter herbage biomass, the combined total likely would have exceeded the winter-only clipping treatment. A reasonable estimate can be calculated by assuming that $30 \%$ of the seasonal midgrass forage is produced by 15 May (NRCS 2011) and using the average production of the midgrass component of $650 \mathrm{~kg} \cdot \mathrm{ha}^{-1}$ (Fig. 3). Defoliation of $25 \%$ of standing forage in mid-May results in $50 \mathrm{~kg} \cdot \mathrm{ha}^{-1}$ removed. If this is replaced through compensatory growth, then the combined total should be at least $700 \mathrm{~kg} \cdot \mathrm{ha}^{-1}$. The additional $50 \mathrm{~kg} \cdot \mathrm{ha}^{-1}$ of herbage would provide 1.3 animal unit days (AUD) $\cdot \mathrm{ha}^{-1}$ of grazing given consumption of $11.2 \mathrm{~kg}$ of intake per animal units (AU; Smart et al. 2010). The loss of this additional forage and the loss of forage availability early in the growing season are two potential costs associated with the strategy of setting aside pastures exclusively for winter grazing. Another cost is the loss of biomass due to senescence after peak standing crop, which often occurs in early July on northern mixed prairie (Sims and Singh 1978; Holderman and Goetz 1981).

Another benefit to early season (May-June) grazing of winter pastures could be the harvest of cheatgrass biomass. Cheatgrass biomass was reduced for all summer clipping treatments compared to the winter-only clipping treatment at Cottonwood (Fig. 2). Cheatgrass would be palatable through mid-June (Haferkamp et al. 1998) and can be consumed by livestock using prescribed grazing methods (Diamond et al. 2009). In addition, Haferkamp et al. (1998) showed the removal of cheatgrass could increase production of western wheatgrass by $150 \mathrm{~kg} \cdot \mathrm{ha}^{-1}$ through increased tillering, potentially providing an additional 3.3 AUD $\cdot \mathrm{ha}^{-1}$ using the assumptions described earlier. Our study demonstrated that 3 consecutive yr of clipping in mid-May or mid-June reduced cheatgrass compared to clipping in July or August, presumably because, by July, cheatgrass would have matured and set viable seed. Clipping cheatgrass as seed production occurs has been demonstrated to reduce seed production; thus potentially reducing stands over time (Hempy-Mayer and Pyke 2008).

Our second hypothesis was that forage quality of winter standing herbage would be improved by summer clipping compared to winter clipping alone, as proposed by Anderson and Scherzinger (1975). Pitt (1986), for example, examined the fall forage quality response of bluebunch wheatgrass (Agropyron spicatum [Pursh] Scribn. \& J.G. Sm.) defoliated in the spring at different stages of maturity and showed that $\mathrm{CP}$ and ADF were improved by clipping at later growth stages compared with plants clipped in the boot or early flowering stage. Similar results were observed by Westenskow-Wall et al. (1994) when bluebunch wheatgrass was defoliated in June. Our data, however, did not support this hypothesis; crude protein levels were not affected by the clipping treatments. We expected that clipping could impact forage quality in western wheatgrass in at least two ways. In the first, clipping might stimulate vegetative growth, likely through tillering. The limited spring precipitation at both stations in 2003 and 2004, however, likely eliminated any opportunity for regrowth following spring defoliation. Defoliation in July and August would have removed the apical meristem of most western wheatgrass tillers and regrowth could only have come from basal buds. Moisture is typically inadequate, however, to stimulate regrowth of basal buds of western wheatgrass during this period (A. J. Smart, personal observation, 2005).

We also expected that clipping could delay the maturation process, resulting in higher forage quality. That also appears to have not occurred in this study. Crude protein is generally highest when plants are vegetative, and declines as they mature. In most years, very few western wheatgrass tillers produce flowers; they typically remain vegetative throughout the growing season (White 1983). Maturity for these vegetative tillers, then, is associated with tiller elongation and the elevation of the apical meristem rather than phenological advancement toward flowering. Rauzi et al. (1969) demonstrated crude protein for vegetative western wheatgrass tillers declining steadily from $14.5 \%$ in late June to $4.7 \%$ in fall.

The only significant differences in forage quality in this study were found in the site-by-year interaction. Crude protein increased at both stations from 2003 to 2004, whereas NDF and ADF decreased (Table 4). These forage quality differences are likely related to the decline in spring precipitation at both stations from 2003 to 2004 (Table 2). Often drought or poor soils impede maturation, causing plants to remain leafier and maintain higher forage quality (Anderson and Scherzinger 1975). Thus it is reasonable to expect that the lower spring precipitation (Table 2) at the Antelope Station in 2004 (37\% of long-term spring precipitation at Antelope compared to $48 \%$ at Cottonwood) resulted in higher $\mathrm{CP}$ that year compared to Cottonwood.

Finally, this clipping study supported our third hypothesis that combining growing-season and dormant-season utilization could increase herbage removal without causing the undesirable shift in plant functional group composition expected with heavy growing-season grazing (see Hart and Balla 1982). The effect of combinations of summer and winter clipping to achieve $65 \%$ total utilization were not different than clipping to $50 \%$ utilization for any of the biomass variables measured in August $2006(\mathrm{P} \geq 0.05)$. Timing of summer clipping had greater influence. After 3 consecutive yr of clipping in June, midgrass biomass (measured end of summer, 2006) was lower than for most of the other clipping treatments (Fig. 3). Research evaluating cumulative effects of multiple year $(\geq 3)$ clipping date treatments on western wheatgrass is very limited. In most studies, plants were clipped to $5 \mathrm{~cm}$ or less, achieving a utilization $>80 \%$ (Trlica et al. 1977; Holderman and Goetz 1981; Stroud et al. 1985; Haferkamp et al. 1998). Stroud et al. (1985), for example, clipped individual tillers over 2 yr on up to four dates per year at varying utilization levels (four of five clip treatments averaged $\geq 74 \%$ utilization). All clipping treatments produced similar biomass in the third year except the most severe treatment (plants clipped four times each summer to $2.5 \mathrm{~cm}$ for $2 \mathrm{yr}$ ), which produced much lower biomass. Zhang and Romo (1994), showed no consistent clipping date effects on shoot biomass of northern wheatgrass after $3 \mathrm{yr}$ of repeated clipping. They did find that all clipping 
dates and intervals reduced the biomass of crowns, rhizomes, and roots compared to the undefoliated control (Zhang and Romo 1994). According to Pitt (1986), bluebunch wheatgrass mortality increased with advancing maturity of a prior year defoliation and that flowering stem number was lowest when plants had previously been defoliated at flower emergence. Ganskopp (1988) found a similar pattern in Thurber's needlegrass (Stipa thurberiana Piper). Herbage and root biomass of Thurber's needlegrass was reduced most by defoliation during the early-boot stage; the effect of defoliation was less severe when it occurred at vegetative, late-boot, or anthesis stages (Ganskopp 1988).

The effect of timing of grazing on the shortgrass component (mainly blue grama and buffalograss) was the opposite of midgrasses. Final treatment response of shortgrass biomass was greater for the June clipping treatment at Cottonwood compared to all other clipping treatments. At Antelope, however, the only difference between FTR shortgrass biomass was between the June and August clipping treatments (Fig. 4), with the June clipping producing the greater FTR shortgrass biomass. Buffalograss and blue grama have been identified as increasers in the mixed-grass prairie (Johnson et al. 1951), so an increase in those species occurring in conjunction with a decrease in midgrass species is consistent with that concept. As noted above, clipping treatments primarily affected the midgrasses, so it is reasonable to assume that an increase in shortgrasses is a result of a detrimental effect of clipping on the midgrasses. June clipping treatments likely weakened western wheatgrass vigor; this then allowed shortgrass species, which escaped the direct effects of defoliation due to their prostrate stature and later growing season, to grow with less competition, as explained by the grazing resistance hypothesis (Briske 1996). Summer precipitation also might have been an important factor. At Cottonwood, summer precipitation ranged from $17 \%$ to $51 \%$ of long-term average (Table 2). A reduction in western wheatgrass vigor likely reduced soil moisture use by that species, increasing soil moisture availability to shortgrasses. At Antelope, summer moisture was less restricted (ranging from $59 \%$ to $219 \%$ of long-term average; Table 2). Thus, release of soil moisture for use by shortgrasses, due to reduced use by midgrasses, is less likely to be important to shortgrass growth at that station.

Responses to timing of summer defoliation observed in our study reinforce the recommendation that managers change season of use; that is to avoid grazing the same pasture the same time every year. Of particular concern is grazing during time periods when the most sensitive species are most vulnerable to the effects of defoliation. Numerous studies have indicated that grasses are particularly sensitive to defoliation from early boot stage to late flowering (see review by Heady and Child 1994); western wheatgrass enters the early boot stage in mid-June in the northern Great Plains (Kamstra 1973). Defoliation in June for $3 \mathrm{yr}$ led to lower western wheatgrass biomass at both Antelope and Cottonwood and higher warmseason shortgrass biomass at Cottonwood compared to repeated defoliation at other time periods. Clearly, grazing strategies that include grazing the same pastures at the same time of year have great potential to alter the species composition of the rangeland, and this shift can occur very quickly in some ecosystems.

\section{IMPLICATIONS}

This study identified two strategies that could be useful on northern Great Plains mixed-grass prairie for increasing pasture utilization without causing an undesirable shift in plant community composition: 1) use of a winter pasture early in the growing season at low utilization so that sufficient growing season and leaf area remain to favor regrowth, resulting in winter standing herbage comparable to an ungrazed winter pasture, and 2) divide pasture use between the growing season and dormant season in a manner to achieve $65 \%$ total utilization (growing-season use limited to $\leq 50 \%$ removal). In practice, the first strategy could be implemented using a quick rotation at a light stocking rate ("flash grazing") prior to initiation of flowering of midgrass species (mid-May in the northern Great Plains). Utilization should not exceed $25 \%$ to ensure adequate remaining leaf area. Defoliation needs to occur early in the growing season so that there is a high probability of growing conditions favorable for regrowth for a sufficient duration. The second strategy could be practiced by allocating one portion of the $65 \%$ total annual pasture use into a growing-season grazing period and another during a dormantseason grazing period. The combination of season of use and intensity is less restrictive than with the first strategy, except growing-season utilization should not exceed $50 \%$.

This study also reinforces the recommendation that managers should change season of use for the growing-season portion of grazing on an annual basis. Three consecutive $\mathrm{yr}$ of defoliating mixed-grass prairie vegetation in the early flowering stage (mid-June in the northern Great Plains) caused a decrease in desirable midgrasses and an increase in less desirable shortgrasses. There are, of course, limitations with the applicability of this study. The first is that this clipping study was conducted on small plots. Further research should be conducted to evaluate these strategies on a larger landscape scale using grazing animals. The second is that the grazing strategy recommendations made as a result of this study are specific to the mixed-grass prairie of the northern Great Plains. The overall concept of increasing pasture utilization by combining growing and nongrowing-season grazing, however, might have very broad application. Thus, it is important that other studies occur that evaluate opportunities to increase utilization levels through combinations of growing and nongrowing-season grazing that are appropriate for ecosystems in other regions.

\section{LITERATURE CITED}

Anderson, E. W., AND R. J. Scherzinger. 1975. Improving quality of winter range forage for elk by cattle grazing. Journal of Range Management 28:120-125.

AOAC. 1990. Official methods of analysis. 15th ed. Arlington, VA, USA: Association of Official Analytical Chemists. $1298 \mathrm{p}$.

ARCHER, S. 1999. Woody plant encroachment into southwestern grasslands and savannas: rates, patterns, and proximate causes. In: M. Vavra, W. A. Laycock, and R. D. Pieper. [EDS.]. Ecological implications of livestock herbivory in the west. 2nd. Ed. Denver, C0, USA: Society for Range Management. p. 13-68.

BrISKE, D. D. 1996. Strategies of plant survival in grazed systems: a functional interpretation. In: J. Hodgson and A. W. Illius [EDS.]. The ecology and management of grazing systems. New York, NY, USA: CAB International. $p$. $37-67$. 
Briske, D. D., AND J. H. Richards. 1994. Physiological responses of individual plants to grazing: current status and ecological significance. In: M. Vavra, W. A. Laycock, and R. D. Pieper [EDS.]. Ecological implications of livestock herbivory in the west. Denver, C0, USA: Society for Range Management. p. 147-176.

Diamond, J. M., C. A. Call, and N. Devoe. 2009. Effects of targeted cattle grazing on fire behavior of cheatgrass-dominated rangeland in the northern Great Basin, USA. International Journal of Wildland Fire 18:944-950.

DormaAR, J. F., AND W. D. Willms. 1998. Effect of forty-four years of grazing on fescue grassland soil. Journal of Range Management 51:122-126.

Ganskopp. 1988. Defoliation of Thurber needlegrass: herbage and root responses. Journal of Range Management 41:472-476.

Goering, H. K., And P. J. Van Soest. 1970. Forage fiber analyses (apparatus, reagents, procedures, and some applications). Washington, DC, USA: Government Printing Office. USDA Agricultural Handbook 379. 20 p.

Haferkamp, M. R., R. K. Heitschmidt, and M. G. Karl. 1998. Clipping and Japanese brome reduce western wheagrass standing crop. Journal of Range Management 51:692-698.

HaRT, R. H., AND E. F. Balla. 1982. Forage production and removal from western and crested wheatgrasses under grazing. Journal of Range Management 35:362366.

Heady, H. F., and R. D. Child. 1994. Rangeland ecology and management. Boulder, CO, USA: Westview Press. $521 \mathrm{p}$.

Heitschmidt, R. K., J. R. Frasure, D. L. Price, and L. R. Rittenhouse. 1982. Short duration grazing at the Texas Experimental Ranch: weight gains of growing heifers. Journal of Range Management 35:375-379.

Hempy-Mayer, K., and D. A. Pyke. 2008. Defoliation effects on Bromus tectorum seed production: implications for grazing. Rangeland Ecology \& Management 61:116123.

High Plains Regional Climate Center. 2011. Automated weather data network. Lincoln, NE, USA: University of Nebraska. Available at: http://www.hprcc.unl.edu/index. php. Accessed 1 February 2011.

Holderman, C. A., And H. Goetz. 1981. Response of western North Dakota mixed grass prairie to intensive clipping and five stages of development. Journal of Range Management 34:188-193.

Holechek, J. L., R. D. Pieper, and C. H. Herbel. 2001. Range management: principles and practices. Upper Saddle River, NJ, USA: Prentice Hall. 587 p.

Johnson, L. E., L. A. Albee, R. 0. Smith, and A. L. Moxon. 1951. Cows, calves, and grass. Brookings, SD, USA: South Dakota State College. South Dakota Agricultural Experiment Station Bulletin 412. 39 p.

KamstRA, L. D. 1973. Seasonal changes in quality of some important range grasses. Journal of Range Management 26:289-291.

Lauenroth, W. K., D. G. Milchunas, J. L. Dodd, R. H. Hart, R. K. Heitschmidt, and L. R. RitTenhuse. 1999. Effects of grazing on ecosystems of the Great Plains. In: M. Vavra, W. A. Laycock, and R. D. Pieper [EDs.]. Ecological implications of livestock herbivory in the west. Denver, C0, USA: Society for Range Management. p. 69100.

McCalla, G. R., II, W. H. Blackburn, and L. B. Merrill. 1984. Effects of livestock grazing on sediment production, Edwards Plateau of Texas. Journal of Range Management 37:291-294.

Mcllvain, E. H., AND M. C. Shoop. 1961. Stocking rates and grazing systems for producing forage and beef on sand sage rangelands-a 20-year study. Woodward, OK, USA: USDA-ARS Southern Great Plains Field Station. Mimeo. $90 \mathrm{p}$.

McNaughton, S. J. 1979. Grazing as an optimization process: grass-ungulate relationships in the Serengeti. American Naturalist 113:691-703.

MilleR, R. F., T. J. SveJcAR, AND N. E. WeSt. 1999. Implications of livestock grazing in the intermountain sagebrush region: plant composition. In: M. Vavra, W. A.
Laycock, and R. D. Pieper [EDS.]. Ecological implications of livestock herbivory in the west. Denver, CO, USA: Society for Range Management. p. 101-146.

NRCS. 2011. Clayey 13-16" PZ ecological site description R060AY011SD. USDANRCS Electronic Field Office Technical Guide. Available at: http://efotg.sc.egov. usda.gov/references/public/SD/R060AY011SD-CLAYEY.pdf. Accessed 4 March 2011.

PITT, M. D. 1986. Assessment of spring defoliation to improve fall forage quality of bluebunch wheatgrass (Agropyron spicatum). Journal of Range Management 39:175-181.

Rauzi, F., AND C. L. Hanson. 1966. Water intake and runoff as affected by intensity of grazing. Journal of Range Management 19:351-356.

Rauzi, F., L. I. Painter, and A. K. Dobrenz. 1969. Mineral and protein content of blue grama and western wheatgrass. Journal of Range Management 22:47-49.

SAS. 2006. SAS Online Doc 9.1.3. Cary, NC, USA: SAS Institute, Inc. Available at: http://support.sas.com/onlinedoc/913/docMainpage.jsp. Accessed 1 September 2011.

Sims, P. L., AND J. S. Singh. 1978. The structure and function of ten western North American grasslands: II. intra-seasonal dynamics in primary producer compartments. Journal of Ecology 66:547-572.

Smart, A. J., J. D. Derner, J. R. Hendrickson, R. L. Glllen, B. H. Dunn, E. M. Mousel, P. S. Johnson, R. N. Gates, K. K. Sedivec, K. R. Harmoney, J. D. Volesky, AND K. C. OLson. 2010. Effects of grazing pressure on efficiency of grazing on North American Great Plains rangelands. Rangeland Ecology \& Management 63:397-406.

Smart, A. J., B. H. Dunn, P. S. Johnson, L. Xu, and R. N. Gates. 2007. Using weather data to explain herbage yield on three Great Plains plant communities. Rangeland Ecology \& Management. 60:146-153.

Soll SuRvey Staff. 2011. Web Soil Survey. USDA-NRCS. Available at: http:// websoilsurvey.nrcs.usda.gov. Accessed 8 March 2011.

Steel, R. G. D., And J. H. Torrie. 1980. Principles and procedures of statistics: a biometrical approach. New York, NY, USA: McGraw Hill Inc. 633 p.

Stroud, D. O., R. H. HaRt, M. J. Samuel, and J. D. Rodgers. 1985. Western wheatgrass responses to simulated grazing. Journal of Range Management 38:103-108.

StuBbendieCK, J., S. L. HATCH, AND C. H. ButTerfield. 1992. North American range plants. 4th ed. Lincoln, NE, USA: University of Nebraska Press. 493 p.

TrLICA, M. J., M. BuwAI, AND J. W. MenkE. 1977. Effects of rest following defoliations on the recovery of several range species. Journal of Range Management 30:21-27.

Undersander, D. J., D. R. Mertens, and N. Thiex. 1993. Forage analyses procedures. Omaha, NE, USA: National Forage Testing Association. $154 \mathrm{p}$.

Vallentine, J. 1990. Grazing management. San Diego, CA, USA: Academic Press, Inc. $533 \mathrm{p}$.

Wallace, L. L. 1990. Comparative photosynthetic responses of big bluestem to clipping versus grazing. Journal of Range Management 43:58-61.

Westenskow-Wall, K. J., W. C. Krueger, L. D. Bryant, and D. R. Thomas. 1994. Nutrient quality of bluebunch wheatgrass regrowth on elk winter range in relation to defoliation. Journal of Range Management 47:240-244.

WHITE, L. M. 1983. Seasonal changes in yield, digestibility, and crude protein of vegetative and floral tillers of two grasses. Journal of Range Management 36:402-405.

Willms, W. D., S. Smoliak, and W. Balley. 1986. Herbage production following litter removal on Alberta native grasslands. Journal of Range Management 39:536540 .

ZHANG, J., AND J. T. Romo. 1994. Defoliation of a northern wheatgrass community: above- and belowground phytomass productivity. Journal of Range Management 47:279-284. 